\title{
Atrioventricular block occurring during a gout attack
}

\section{Gut atağı sırasında oluşan atriyoventriküler blok \\ Kazım Serhan Özcan*, Servet Altay, Damirbek Osmonov, Barış Güngör, Adem Tatlisu}

Cardiology Department (K. S. Özcan, MD, S. Altay, MD, D. Osmonov, B. Güngör, MD, A. Tatlısu, MD), Siyami Ersek Cardiovascular and Thoracic Surgery Center Teaching and Research Hospital, TR-34817 İstanbul

\begin{abstract}
The relationship between uric acid levels and cardiovascular disease has been known since the 19th century and many reports do exist in the literature that show the association of increased uric acid levels with gout, hypertension, obesity and cardiovascular disease. However, atrioventricular block was rarely reported in relation with, which can usually be resolved with antiinflamatory and uric acid lowering therapies. Here, we reported a patient with gout attack and complete atrioventricular block. Atrioventricular conduction improved after antiinflamatory and uric acid lowering therapy in our patient and the patient did not require a permanent pacemaker.
\end{abstract}

Keywords: Hyperuricemia, atrioventricular block, gout

\section{Özet}

Ürik asit düzeyleri ve kardiyovasküler hastalık ilişkisi ondokuzuncu yüzyıldan beri bilinmektedir ve artmış ürik asit seviyelerini literatürde gut, hipertansiyon, obezite ve kardiyovasküler hastalıklar ile ilişkilendiren çok sayıda makale bulunmaktadır. Tüm bunların yanında ürik asit düşürücü ve antiinflamatuar tedavi ile düzelebilen atriyoventriküler blok nadiren bildirilmiştir. Biz burada eş zamanlı olarak gut atağı ve atriyoventriküler blok olan bir hastayı sunduk. Hastamızda antiinflamatuar ve ürik asit düşürücü tedavi sonrası atriyoventriküler iletim düzeldi ve hasta kalıcı pil ihtiyacı göstermedi.

Anahtar sözcükler: Hiperürisemi, atriyoventriküler blok, gut

Geliş tarihi/Received: September 27, 2011; Kabul tarihi/Accepted: February 15, 2012

\section{*Corresponding author:}

Dr. Kazım Serhan Özcan, Kardiyoloji Bölümü, Siyami Ersek Göğüs Kalp ve Damar Cerrahisi Eğitim Araştırma Hastenesi, TR-34087 İstanbul. E-mail: serhandr@gmail.com

\section{Introduction}

Atrioventricular (AV) block may have multiple causes including acute myocardial infarction, chronic ischemic heart disease, infectious disease, tumors, autoimmune connective tissue disorders, cardiac surgery, metabolic and neuromuscular disorders, drugs and electrolyte imbalances. Elevated levels of uric acid and gout are considered to be associated with atrioventricular block by some authors [1-3]. However spontaneous normalization of atrioventricular conduction with medical treatment is rarely reported in literature [1]. We hereby report a case of atrioventricular block occurring during a gout attack with elevated uric acid levels. 


\section{Case report}

A 63-year-old man was admitted to our emergency department after a syncopal episode which developed thirty minutes before his arrival to hospital. On admission he had complaints of pain and swelling in his right metatarso-phalangeal joint for twelve hours. He had diagnosis of gout arthritis for five years which was confirmed by synovial fluid analysis. The patient did not experience an attack for one year and he was not on any medication. The patient was otherwise healthy and did not have a syncope episode before. There was no family history of cardiac disease. On physical examination; the patient was diaphoretic, blood pressure was $82 / 56 \mathrm{mmHg}$ with a heart rate of 39 beats per minute and respiratory rate was 22 per minute. The patient's heart sounds were normal with no murmurs. His temperature was $37^{\circ} \mathrm{C}$. Electrocardiography revealed complete AV block (Figure 1). The patient was immediately taken to intensive care unit and a temporary pacemaker was implanted for symptomatic AV block. CBC showed mild leukocytosis $(11.300 \mu / \mathrm{L})$. Troponin and CK-MB levels were within normal ranges at admission and were not elevated during the follow-up. Blood chemistry tests including blood urea nitrogen, creatinine, aminotransferases were all within normal ranges. CRP and uric acid levels were elevated; $8.4 \mathrm{mg} / \mathrm{dL}[0-5 \mathrm{mg} / \mathrm{dL}]$ and $14.1 \mathrm{mg} / \mathrm{dL}[2.4-5.7 \mathrm{mg} / \mathrm{dL}]$ respectively. Chest radiography was normal and transthoracic echocardiography showed a left ventricle with normal internal dimensions (diastolic dimension: 4.6/ systolic dimension: 2.4) with an ejection fraction of $64 \%$, normal wall thickening (both interventricular septum and posterior wall were $9.5 \mathrm{~mm}$ ), mild mitral regurgitation and mild tricuspid regurgitation. There was no evidence of pericardial thickening or effusion and calcification or degeneration on valves. The patient was consulted with rheumatology department. An acute attack of gout arthritis was diagnosed and treatment with colchicine and indomethacin was begun. On the second day we started allopurinol treatment.. After the treatment the symptoms of the patient improved and AV block resolved on the fifth day of the treatment (Figure 2). On the same day the patient's uric acid level was 5.5 $\mathrm{mg} / \mathrm{dL}$ [2.4-5.7 mg/dL], CRP level was $4.3 \mathrm{mg} / \mathrm{dL}$ [0-5 mg/dL]. To exclude ischemia, we performed myocardial perfusion scintigraphy and there was no ischemia. On the seventh day of the treatment he was still on normal sinus rhythm and was discharged. We didn't consider a permanent pacemaker due to transient nature of the block. On the follow up period for one year he was free of symptoms, his uric acid level and holter electrocardiogram was normal.

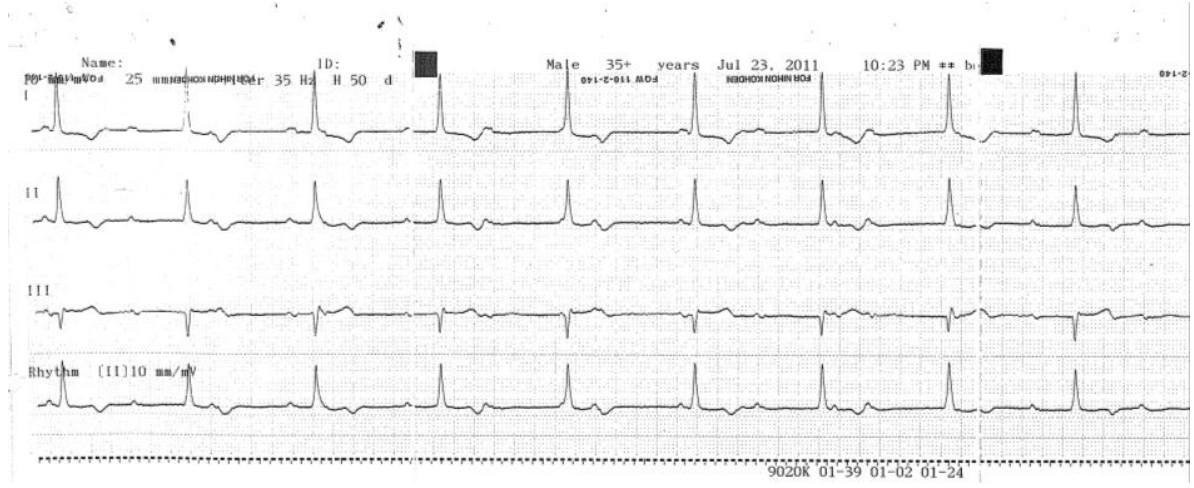

Figure 1. Initial rhythm trace consistent with complete AV block. 


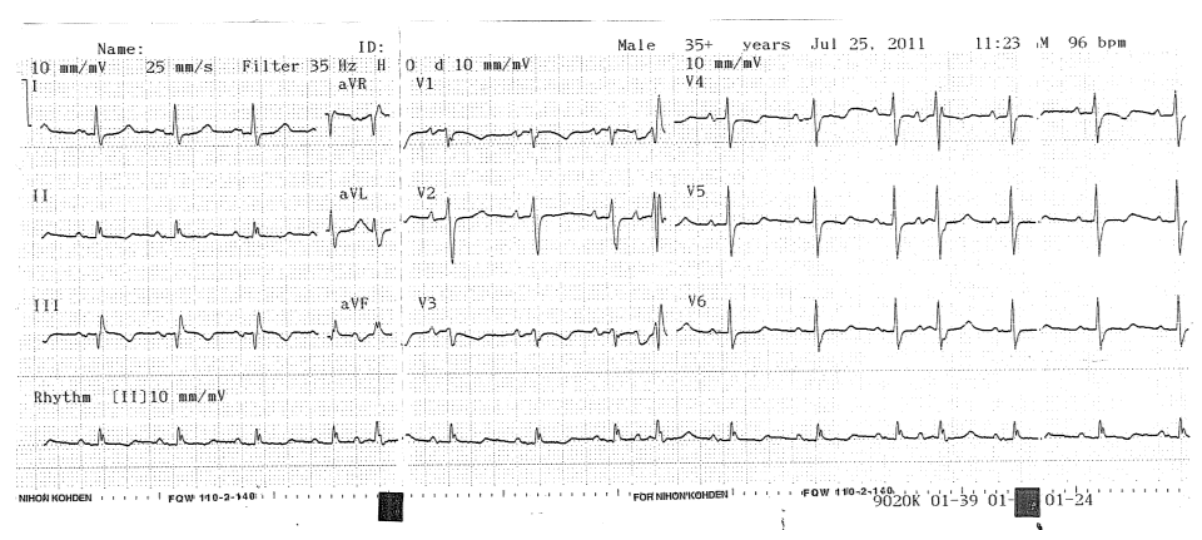

Figure 2. Electrocardiography on the fifth day showing normal sinus rhythm.

\section{Discussion}

The relationship between gout and cardiovascular disease is not uncommon. Gouty deposits have been found in the myocardium, the cardiac valves and the intima of the coronary arteries [4]. Thus, hyperuricemia may precipitate the atherosclerosis, tophus on cardiac valves, hypertension and myocardial infarction [5-7]. Transient or persistent AV block of varying degrees can occur in a variety of clinical situations. Gouty deposits in the myocardium may disrupt AV conduction system and cause AV block. Virtanen et al. reported a man with atrioventricular block occurring during a gout attack with elevated uric acid levels. They have suggested that cause of the block was urate deposit in the conduction system. In their case after urate lowering treatment the block has resolved spontaneously [1]. Laurens et al observed 158 patients with permanent pacemaker implantation. The patients in the pacemaker group had markedly increased uric acid levels compared with the control group. They have offered screening the uric acid levels in patients with atrioventicular block routinely and suggested that treatment with urate lowering drugs may improve atrioventricular conduction [2, 3]. In this case atrioventricular block occured just after symptoms of the gout arthritis started and we couldn't figure out any cause for the AV block.)AV block may have been triggered by elevated levels of uric acid. Elevated levels of uric acid may cause inflammation on the conduction system and it may cause transient or permanent AV block.

We consider that the nature of AV block would change in relation with the duration of the damage of gouty deposits on AV conduction system, and became persistent if the initiation of the therapy delays. Although our patient had elevated serum uric acid levels for five years, he was not on any medication. However, the AV block did resolve after the appropriate therapy for gout attack and elevated uric acid levels. Thus, we suggested that the irreversible damage of AV conduction caused by uric acid deposits in the myocardium needs decades. Elevated levels of uric acid should be kept in mind as a trigger for atrioventricular block and urate reducing therapy may be a treatment option to resolve a conduction block.

\section{References}

1. Virtanen KS, Halonen PI. Total heart block as a complication of gout. Cardiologia 1969; 54: 359-63.

2. Laurens P, Gavelle P, Maurice P, Dubost C. Incidence of hyperuricemia in atrioventricular block. Systematic study of 158 cases which required implantation of an isotopic cardiac pacemaker. Arch Mal Coeur Vaiss 1978; 71: 922-8.

3. Laurens P, Gavelle P, Maurice P. Occurrence of hyperuricemia in atrioventricular block. (Results of a study of 158 patients with isotopic pacemaker implantations. C R Acad Sci Hebd Seances Acad Sci D 1976; 27; 283: 1257-60.

4. Talbott, J. H.: Gout, 3rd ed. (GRUne \& Stratton, New York 1967). 
5. De Vera MA, Rahman MM, Bhole V, Kopec JA, Choi HK. Independent impact of gout on the risk of acute myocardial infarction among elderly women: a population-based study. Ann Rheum Dis 2010; 69: 1162-4.

6. Gagliardi AC, Miname MH, Santos RD. Uric acid: A marker of increased cardiovascular risk. Atherosclerosis 2009; 202: 11-7.

7. Chobanian AV, Bakris GL, Black HR, Cushman WC, Green LA, Izzo JL Jr, Jones DW, Materson BJ, Oparil S, Wright JT Jr, Roccella EJ; Joint National Committee on Prevention, Detection, Evaluation, and Treatment of High Blood Pressure. National Heart, Lung, and Blood Institute; National High Blood Pressure Education Program Coordinating Committee. Seventh report of the Joint National Committee on Prevention, Detection, Evaluation, and Treatment of High Blood Pressure. Hypertension 2003; 42: 1206-52. 